\title{
Certificate of Ethics in Accounting and Professional Independence of Accountants
}

\author{
Grażyna Voss \\ University of Technology and Life Sciences, Faculty of Management, Bydgoszcz, Poland,
}

\begin{abstract}
Ethical standards in accounting constitute an important element in the functioning of economic entities and in presenting reliable financial information used by all stakeholders when taking important decisions. In order to analyse the issue of using accounting ethics, a survey which indicated the determinants of unethical behaviour and the possibilities for improving the situation in terms of their observing and ways of strengthening their independence was conducted. Following the study, a concept of implementing an account books certificate which estimates their accuracy in the legal and ethical aspects was formulated.
\end{abstract}

Keywords: Certificate of Ethics in Accounting and Professional Independence of Accountants

\section{Introduction}

When analysing the concept of social responsibility, the issue that constitutes the background for this concept, which is ethics, must be mentioned. Companies which want to be seen as socially responsible should maintain a high level of corporate culture and remember about ethical conduct. Codes of ethics which should include information about the values, convictions and standards of behaviour accepted by a company are the instrument that facilitates observance of ethical standards. Codification of standards of conduct proves that a company observes high ethical standards. It is for the Management Board of a company to formulate the rules of ethical conduct so that employees' attention is drawn to a certain value system and they are also encouraged to create a positive image of their company. Making right business decisions that base on ethical standards contributes to building proper relations with the environment, it inspires stakeholders' trust and creates positive image of a company.

Unethical behaviour of business people observed both in Poland and abroad has practically no negative implications. It may be assumed that the absence of serious condemnation of unethical practices in business as well as their justifying give rise to the low ranking of ethical standards in the hierarchical structure of values. ${ }^{1}$

The introduction of appropriate procedures should facilitate performing ethical evaluations by persons responsible for the decision-making process. Ethical standards should be clear and comprehensible for everyone and respected in a given entity. ${ }^{2}$ Introducing internal codes of ethics by modern companies and creating codes of professional ethics has become common, and their analysis and interpretation constitutes a subject of various studies and trainings.

Therefore, the issue of professional ethics of workers of accounting departments is worth considering. It must be emphasised that the issues of ethical conduct in a company should be considered to be a condition of an authentic responsibility in relation to undertaken and performed tasks and their short- and long-term effects. The work of an accountant should be founded on the principles strictly defined in codes of professional conduct. Thanks to the actions taken by the Accounting Standards Committee of the Research Council of the Accountants Association in Poland, "Code of Professional Ethics in Accounting" was prepared. Its main aim is to provide persons engaged in accounting with the knowledge of procedures in the field of professional activities. The code includes not only ethical and moral principles, but

\footnotetext{
${ }^{1}$ S. Sugahara, G. Boland, 2011. Faculties' perceptions of ethics in the accounting curriculum: a Japanese study. [in:] C. Jeffrey, Research on professional responsibility and ethics in accounting, Emerald Group Publishing Limited, Bingley, U.K., p. 198.

2 J. Niemczyk, 2011. Metodologia nauk o zarzadzaniu. [in:] Podstawy metodologii badań w naukach o zarzadzaniu, W. Czakon, ed. Oficyna a Wolters Kluwer business, Warszawa, p. 26, see also A. Kaczmarczyk, 2003. Badania marketingowe. Metody i techniki. PWE Warszawa, p. 97.
} 
also information on the attitudes and expectations of accountants. It can be assumed that the code constitutes a type of set of values which all persons professionally engaged in accounting should be guided by. ${ }^{1}$

The expectations of persons engaged in accounting are currently very high. Therefore, professional accountants should apply the ethical standards which specify their procedures within specific activities. Taking into consideration the role accountants play in the economic decision-making process, they must be aware of the consequences that can result from not following ethical standards. ${ }^{2}$

Taking into account the above mentioned considerations, it must be emphasised that nowadays accountants act in dynamically changing and competitive environment. Whether or not they act ethically is in a certain way a testimony of humanity, because basic ethical standards were created on the basis of collective moral standards. Taking into consideration accounting failure in estimating ethics of a company, the protection of integrity of content and legibility of accounting play a major role.

The aim of the article is to present the results of a survey and to formulate a recommendation for professional associations and economic entities in the area of observing standards of professional ethics in accounting and of informing stakeholders about the way of implementing and observing the standards.

\section{The Evaluation of the Use of Ethical Standards in Accounting}

The study was conducted by means of a prepared questionnaire ${ }^{3}$ including an instruction concerning the manner of answering the questions. The questionnaire was sent to 272 employed people, 118 correctly completed questionnaires were received, which is $43.4 \%$ of the sent ones. The questionnaire consisted of the following groups of questions:

questions concerning ethical and unethical behaviour

questions concerning independence of accountants and accuracy of account books

questions concerning basic information about the respondent

The study, its analysis and interpretation resulted in creating a concept of introducing a system which would assure quality and observance of ethical standards by accountants in the area of bookkeeping.

All the respondents ${ }^{4}$ are employed by economic entities of various organisational and legal types. The group of entities which employed the biggest number of respondents consisted of limited liability companies (39 companies) and natural persons conducting economic activity (36 entities). Moreover, the respondents were employed by the public finance sector entities, joint-stock companies and partnerships as well as non-profit entities. Most of the respondents indicated that they worked in economic entities ( 82 entities $-69 \%$ ) that are not required to audit by statutory auditors. Owing to a vast variety

\footnotetext{
${ }^{1}$ A person or a business entity interested in becoming a member of SKwP (Accountants Association in Poland) may become an ordinary member or a supporting member of SKwP. Meeting formal requirements specified in the statute is necessary. An ordinary member may be a Polish citizen with good repute and full legal capacity, working as an accountant or of a neighbouring profession connected with accounting; students of finance and accounting or of neighbouring faculties as well as employees of business entities of the Association; a foreigner being a resident of the Republic of Poland under the law Polish citizens have to comply with http://www.skwp.pl/Czlonkostwo,54.html (10.07.2015).

${ }^{2}$ Compare. G.Voss, 2016. Kształtowanie norm etycznych a odpowiedzialność zawodowa księgowych, Wydawnictwo Uczelniane Uniwersytetu Technologiczno-Przyrodniczego w Bydgoszczy pp. 163-182

- Under this agreement, Italy will take most of Kosovo valley, with cities like Pristina, Ferizaj, Gjilan, Kamenica, the Drenica region, Dukagjini in Peja, Gjakova, Prizren, lands northwest of Plav, Gucci, Rozhaj, Tutin, then Ulcinj, Tuzi, eastern ethnic Albanian areas Tetovo, Gostivar, Kicevo, Struga and a part of Prespa. Within the Italian area with an area of $11,780 \mathrm{~km}$ with a population of 820,000 inhabitants, Albania was joined by 19 prefectures, 13 municipalities, 141 communes, 1,501 villages. For more details see: Arkivi Qendror i Shtetit të Republikës së Shqipërisë (më tej: AQSh), Fondi 267, vitit 1945, dos. 46, p. 32; Ali Hadri, Lëvizja Nacionalçlirimtare në Kosovë (1941-1945), Rilindja, Prishtinë, 1971, p.106; Muhamet Shatri, Kosova në Luftën e Dytë Botërore (1941-1945), Toena, Prishtinë, 1997, p.17;

** Within the German occupation zone due to the industry, the Trepca mines and the underground assets that this region offered and because of Germany's strategic interests, were these territories included as as the regions of Mitrovica, Podujeva and Vucitrna, were included within the quisling state of the Serbs Milan Nedic. For more details see: Ali Hadri, Lëvizja Nacionalçlirimtare në Kosovë (19411945), Rilindja, Prishtinë, 1971, f.97-102; Muhamet Shatri, Kosova në Luftën e Dytë Botërore (1941-1945), Toena, Prishtinë, 1997, p.1742; Historia e Popullit Shqiptar IV, 2008, ,p. 129-130.
} 
in the employment of the respondents, both in the area of the organisational and legal form and in the size of the companies employing the respondents, it can be noted that ethics of accounting refers to all economic entities regardless of their size and legal form.

The questionnaire was completed by employees holding independent positions in the accounting departments, the biggest group consisted of people at the age of 30 to 49 ( 55 people $-46.31 \%$ ) and workers with many years of experience (56 respondents $-47.46 \%$ ) with the work experience of at least 20 years. Long-time professional experience indicates extensive knowledge and practice in accounting, so the responses may be a reliable source of information on the examined issues. The respondents also indicated the scope of duties they dealt with most often at work. In connection with the variety of kind of work, they were allowed to choose more than one answer. 118 respondents chose 538 answers altogether. The activities mentioned most often included preparation of financial statements $(68.54 \%)$ and records and tax settlements $(68.54 \%)$. Moreover, most of the respondents carry out a few of the presented in the questionnaire duties and deal with various activities, which is presented in diagram 1.

Diagram 1. The scope of duties carried out by the respondents most often $(N=538)$

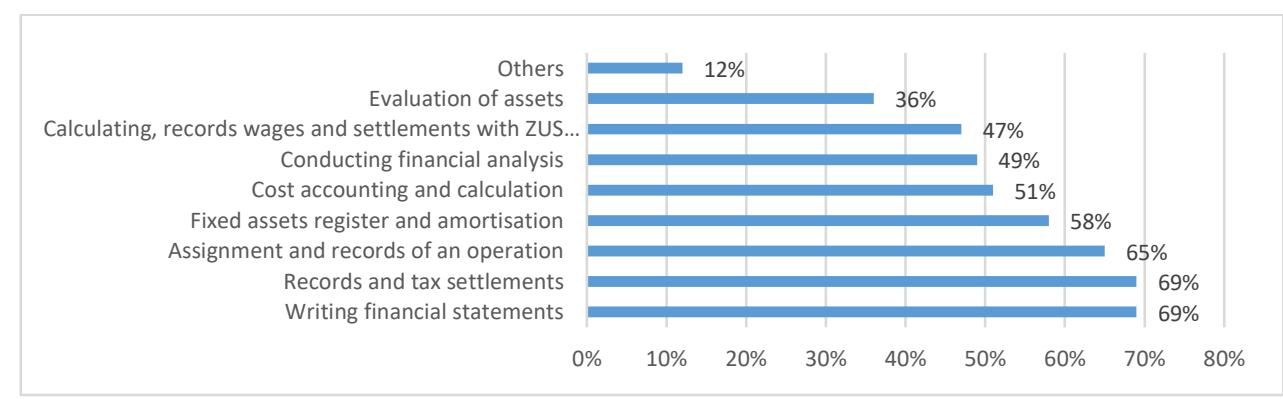

Source: own study

A wide range of duties involves the necessity of professional competence and constant training according to the changing legal and economic conditions.

Almost $85 \%$ of the respondents indicated that the economic entity they were employed by based on the rules in the code of professional conduct and they claimed that the regulation it included ensured that an accountant's work was done in a competent, objective, accurate, professional, honest and responsible way.

The respondents differed when it came to the evaluation of the commonness of unethical behaviour. 57 of them stated that unethical behaviour was common, whereas slightly more of them, $51.69 \%$ were of a different opinion. Nevertheless, in over $70 \%$ of cases, the individuals responsible for the accounting departments in the examined companies often or rarely noticed unethical behaviour in their work (diagram 2).

Diagram 2. The percentage of encounters with unethical behaviour in accounting $(\mathrm{N}=118)$

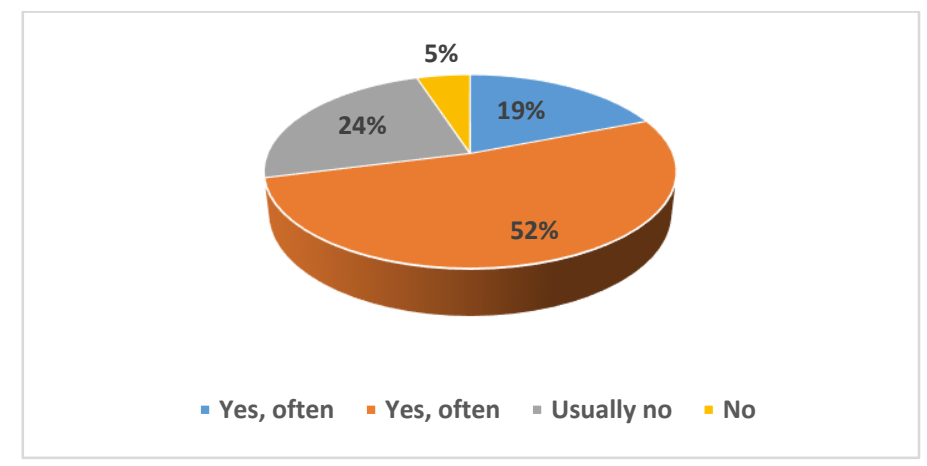




\section{Source: own study}

The conducted research indicates that 84 individuals encountered the lack of compliance with ethical standards, which means that the instances of unethical behaviour are not isolated cases, and in the case of every fifth respondent they are often met.

The respondents were also asked to indicate a few examples of behaviour that in their opinion could lead to unethical conduct. Most of the respondents $(67.80 \%)$ indicated the influence of the persons in charge on their subordinates and the pressure exerted by the management, whose result was to achieve the best results and economic indicators $(62.71 \%)$. More than a half of the respondents drew attention to the fact that unethical behaviour was accompanied by the fear of losing jobs (55.93\%). Another example of conduct considered unethical given by the respondents was the intention to influence financial results (44.92\%). The reason for unethical behaviour in the respondents' opinion was also an attempt to hide past mistakes made in accounting (42.33\%) as well as insufficient autonomy of the main accountant $(35.59 \%)$.

The activities that may encourage violating of ethical standards are of various kinds, but they mostly aim at obtaining benefits resulting from the improvement of results and economic indicators or keeping jobs. The respondents were able to choose more than one answer (118 respondents chose 503 answers), which is presented in diagram 3.

Diagram 3. The assessment of the frequency of the occurrence of certain situations influencing unethical conduct $(\mathrm{N}=503)$

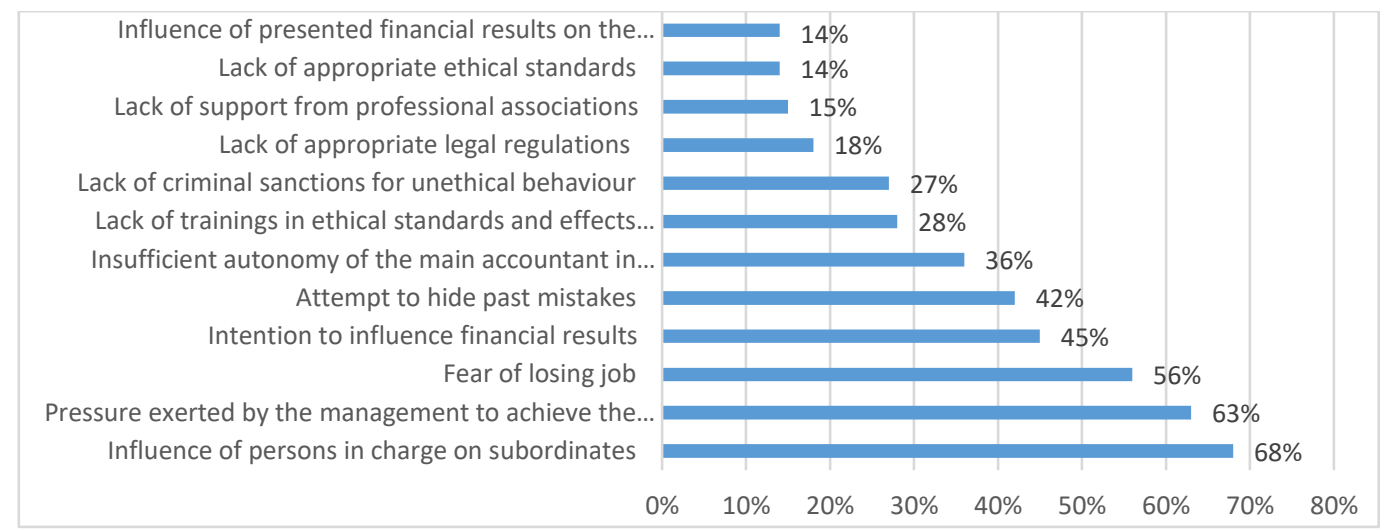

Source: own study

The respondents are inclined to assume that the introduction of a general obligation to audit financial statements by statutory auditors may contribute to enhancing ethical behaviour in accounting and they also stated that such an audit could be conducted every two years.

Answering another question whether in order to ensure greater professional independence of accountants and a more significant role of ethical standards an "organisation" certifying financial and accounting activities and issuing the certificate of ethics in accounting, which would confirm ethical conduct, needs to be established, $60 \%$ of the respondents assumed that establishing such an organisation would ensure more independence of accountants and increase the role of ethical standards in accounting. The respondents believe that the Accountants Association in Poland could be such an institution and certificates should be issued for a maximum of four years.

Introducing certificates would constitute a showcase of a company and a confirmation for stakeholders of its reliability and accuracy in the area of accounting. It would bring numerous benefits for both the interested entities and other stakeholders. Issuing them for the period from two to four years would be justified and would improve the quality of financial and nonfinancial information presented by entities, especially given the fact that in the present situation the entities that are not obliged to audit financial statements are not subject to any form of control (except for controls in the scope of selected legal framework). However, the respondents are inclined to choose the option of a certificate being issued for four years (44.92\%) or depending on the level of risk from two to four years, which should be decided by a committee. 
The respondents were also asked to answer the question concerning their company being a signatory of the Code of Professional Ethics in Accounting. Over 15\% of the respondents (18 people) confirmed the fact that their entity was a signatory (diagram 8). Unfortunately, a hundred respondents are not employed by an economic entity which is a signatory of the Code of Professional Ethics in Accounting. On the basis of the conducted research it is impossible to verify what causes such a low percentage of signatories or what activities can be undertaken in order to change it.

Summarising the results of the research, it is possible to specify the conditions of the functioning and implementing ethical standards in accounting, but a high number of respondents $(70 \%)$ indicating the existence of unethical conduct that they encounter in their workplace gives rise to concern. The research has also allowed specifying the determinants of unethical behaviour, which include in particular the influence of persons in charge on their subordinates and the pressure of the management on receiving the best results possible. Employees being afraid of losing their jobs is also of significant importance. The study has identified the barriers limiting the observance of ethical standards in accounting, the areas in which actions should be taken in order to strengthen and promote ethical conduct, and the expectations of the respondents in the scope of ensuring compliance with the standards. The results help to formulate recommendations for the economy in the form of creating procedures of obtaining a certificate of accounts and presenting information on implementing the solutions included in the Code of professional ethics in accounting by economic entities.

\section{System Modification and Corrective Actions - Account Books Certificate}

The aim of the presented concept of account books certificate is the assessment of the compatibility of the application of legal requirements and ethical standards in accounting which is to ensure the continuation of a given entity's activity as well as guarantee stakeholders reliable and accurate information on the financial condition and the outcome of activities, which allows taking appropriate decisions concerning the future. The assumptions concerning issuing certificates differ considerably from the practices used so far, in which not all economic subjects were subject to supervision and control regarding the accuracy of bookkeeping; the difference results from the fact that the assessment and auditing of accounts and financial reports has not taken into account ethical standards in accounting up till now. Therefore, in the process of issuing certificates the assessment of application of legal requirements with simultaneous observance of ethical standards should be taken into consideration. The starting point of creating the concept of certificate is the assumption that accounting as a source of financial information necessary to take decisions should assume that the persons involved observe the standards of professional ethics and in consequence contribute to building social prestige of the profession.

Creating such a certificate will enable better evaluation of ethical behaviour of people involved in the accounting and financial services, elimination of unethical behaviour, strengthening the role of an accountant as a profession of public trust, increasing its autonomy and creating support for this professional group in its resistance to the pressure of the management, which focuses only on presenting financial results consistent with the expectations of owners and not necessarily with the legal requirements and business ethics. On the other hand, introducing a certificate would be not only a support for people involved in the accounting and financial services, but also a source of information for all stakeholders and market participants.

Introducing a certification system of account books will improve quality and allow defining and supervision of methods and conditions of records in accounts on all the stages of accounting activities basing on legal regulations required for a given (certified) economic entity.

It needs to be observed that in a certification system of account books, developed procedures should relate to all the stages of the work a finance and accounting department, from the moment of organising accounting in a company, through creating documentation required in the scope of bookkeeping, writing reports and declarations including those made for public and legal settlements. Moreover, the procedures need to take into account behaviour required by ethical standards included in the code of ethics. Such a certificate would confirm a high level of professional competence, of the quality of work, and of professional independence, but it would also ensure protection of stakeholders from possible unfavourable events resulting from irregularities and violation of provisions of law. A certificate can constitute an effective tool to control the observance of law in the scope of bookkeeping by economic entities as well as a source of information on the accuracy of account books and observance of ethical standards for both the audited entity, counterparties and other stakeholders. In many cases a certificate can constitute an element of guarantee of choice made by a counterparty and also open the way to cooperation with other entities. It can be an additional advantage which will facilitate applying for EU grants or bank loans 
and trade negotiations. It would constitute a valuable source of information, confirmation of account books accuracy and observance of ethical standards by a professional non-governmental organisation particularly for foreign counterparties.

Summarising, it should be noted that the basic assumptions concerning creating a model of an account books certificate is the evaluation of the following:

professional competence of accountants

quality of work verification

professional independence of accountants connected with creating professional image

appropriate preparation and presentation of information on accounting

appropriate treatment of stakeholders

observing professional confidentiality

Introducing a certificate will not be compulsory, but it can cause an increase in awareness of the finance and accounting environment, reflect the maturity of business ethics among entrepreneurs, increase the independence of accountants and enhance public confidence in the profession of accountant. Similarly, it may increase organisational clarity in an economic entity, influence its prestige and improve its perception among customers and counterparties, which may lead to measurable economic benefits. Such perception of account books certification can be for an entity itself and its environment value added that will enable an entity to limit risk and uncertainty in taking decisions as well as influence the image of an entity and its perception in environment.

\section{Operational Assumptions in Account Books Certification}

In the process of certification, the certifying entity should act impartially and independently, and all entities wanting to confirm the accuracy of bookkeeping and observance of ethical standards specified by the law will be entitled to use its services. Obtaining a certificate will concentrate on two grounds of assessment nature:

Ensuring compliance of bookkeeping with legal regulations.

Assessment of observing ethical standards in accounting.

The assessment of the legal and ethical aspect should give answer whether account books in an entity are kept accurately, reflect the actual situation and fit into wider aspect of business ethics.

Before the regulations of issuing a certificate of account books are established, an analysis needs to be conducted basing on the following questions:

When conditions should the institution issuing a certificate meet?

How will the process of certification be conducted?

What areas will be assessed and examined within the process of certification?

What mechanisms will be use in order to conduct the examination and error correction?

How long will a certificate be issued for and how will the information regarding certified entities be accessible?

How will a certified entity inform stakeholders about their certificate and the way of observing the ethical standards?

The answer to the above mentioned questions will constitute the basis for specifying the path of procedure in the scope of the improvement of account books quality and observing the standards in the code of professional ethics in accounting (drawing 1) and the organisation of certification process (diagram 4).

Drawing 1. 


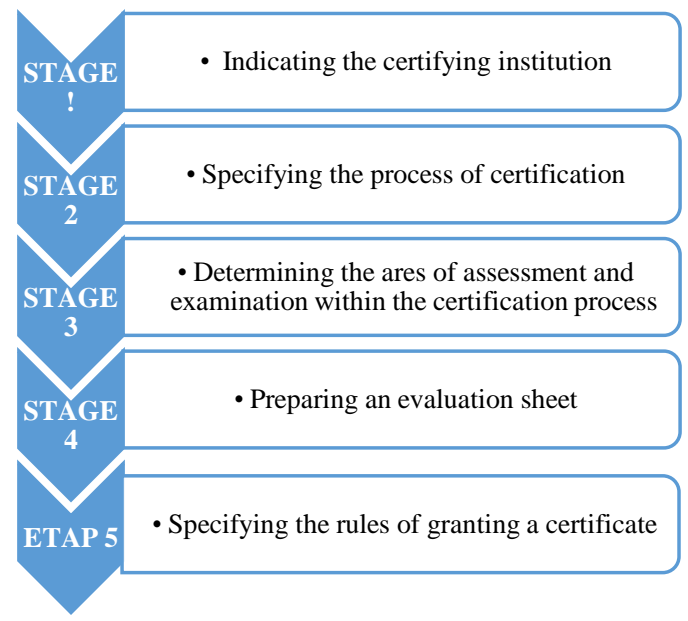

Source: own study

An important element in the process of certification would be the scope of disclosing information on account books certificate and observance of ethical standards in accounting, as it should be made available for users by means of different media, in which way it will be of an informative nature and will allow promoting ethical standards and attitudes. The scope of presenting information is shown in drawing $2 .{ }^{1}$

Diagram 4. Organisation of account books certification process

\footnotetext{
${ }^{\square}$ Thus, on 6 September 1915 in Plle, there was a secret agreement between the Central Powers and Bulgaria for the division of the territories, under which Bulgaria was offered whole Macedonia and Eastern Serbia to the Morava River. According to this agreement in Kosovo and other Albanian territories, two occupation zones were created: the Austro-Hungarian zone and the Bulgarian zone. Within the Bulgarian area were included Podujevo, Pristina, Gnjlane, Kamenica, Viti, Ferizaj, Kacanik, Lipjan, Drenas, Theranda, Prizren and Rahovac. In the south of the Black Mountains of Skopje and the Sharr Mountains, the Bulgarian area included almost all of the eastern Albanian territories, including centers such as Dibra, Ohrid, Struga, Kicevo, Tetovo, Gostivar, Skopje, Kumanovo, Presevo, Bujanovac. So on October 21, Bulgarians entered the southeastern part of Kosovo, and the next day they took Skopje, where the Serbian divisions were stationed in Macedonia and withdrew to the north of Kosovo. The Bulgarians occupied Kaçanik on 25/26 October, while Pristina was captured on 23 November, Ferizaj on 25 November. With the invasion of Skopje and Kumanovo, they cut off all traffic lines to Serbia. However, by the end of this year, the Austro-Hungarian and Bulgarian ruling circles expressed a desire for even greater expansion. After numerous discussions between the two parties on 1 April 1916, an agreement was reached on the delimitation of the military occupied areas in Kosovo beyond the boundaries, set by the secret agreement dated 6 September 1915. This agreement remained in force until 29 September 1918, when Bulgaria capitulated and, as a result, left the war. For more details, see: Jasha Rexhepagiq, Zhvillimi i arsimit dhe i sistemit shkollor të kombësisë shqiptare në territorin e Jugosllavisë së sotme deri në vitin 1918, Enti ¡ Teksteve dhe i Mjeteve Mësimore të Kosovës, Prishtinë, 1968, f.252; Limon Rushtiti, Rrethanat politiko-shoqërore në Kosovë 19121918, Rilindja, Prishtinë 1986, p. 174; Shaban Hashani, Ferizaj dhe rrethina 1873-1941 (vështruar nga pikëpamja historike), Ferizaj, 1998, f.214; Historia e Popullit Shqiptar III, Periudha e Pavarësisë 28 Nëntor 1912- 7 prill 1939, Akademia e Shkencave e Shqipërisë, Toena, Tiranë 2007, p.436; Noel, Malcolm, Kosova një histori e shkurtër, Koha, Prishtinë 2011, p.336-339.
} 
Preparing regulations, documents and rules of granting a certificate, determining objectives and areas subject to verification, preparing assessment criteria

\section{Appointing a certifying committee and presenting its} members

\begin{tabular}{l}
\hline Presenting the schedule of certifying committee \\
\hline Publication of information about issuing certificates \\
and appointing a committee and it starting to work \\
(information on the website of a certifying organisation \\
and in the trade press)
\end{tabular}

Submitting an application form by an economic entity

Examination, analysis and evaluation of documents by the certifying committee

Preparing reports and an assessment card, presenting results of examination of an economic entity in order to respond to the comments (a conversation and reasons in the written form)

\section{Making a decision about granting, conditional granting or non-} recognition of a certificate and communication information (decision) to the persons concerned

Control of the results of taken decisions (appeals, verification) and preparing a report and a list of entities with a certificate
Identifying decision-making problems

Organisation of proces of certification

Source: own study

Drawing 2. The scope of disclosing information on the entities with an account books certificate and observing of the ethical standards in accounting

A list of entities with a certificate on the website of the certifying entity

Information included in a financial statement of a certified entity

An account books certificate and information on observing of ethical standards in accounting by entities

Information on the website of a certified entity
Publication of a list of entities with a certificate in a national monthly magazine for accountants

Source: own study 
The above drawing demonstrates that every entity that has a certificate and observes ethical standards in accounting should inform its stakeholders about this fact by means of different types of media. Only comprehensively presented information can reach a wide group of people who are interested in financial and nonfinancial information and most of all those stakeholders for whom using ethical standards makes managing an entity better, more rational and more socially beneficial.

\section{Summary}

In the modern world certificates are commonly used in various areas of the economic life. Workers of financial and accounting departments can obtain certificates confirming their professional competence, which plays an important role in the recruitment process and in promotion. Still, in the area of account books no certificates can be obtained though they could be a showcase of a company and confirmation of reliability and accuracy of an entity in accounting for stakeholders. Introduction of certification would be beneficial for both the entity and other stakeholders. The process of creating and implementing certificates will not be easy, but good practices could attract interested entities and with time certain types of behaviour will become fashionable and common.

The presented solutions concerning account books certification should be treated as a path of procedure in creating the certification system. The process will not be easy, because it may involve damaging of the currently functioning structure of economic entities, which were not subject to auditing and control by other bodies than national units entitled to control under tax law or social security. On the other hand, it is a way to support for entities which observe the regulations of law and ethical standards in their activity and which receive no feedback concerning their counterparties or competition in the world of financial statements based on financial and nonfinancial data and economic entities creating different explanatory notes and reports on social responsibility of business. The benefits of observing ethical standards in accounting should be reflected in financial reporting. Additional information in the scope of explanation or a separate explanatory note should include information on observing ethical standards in accounting. In this area entities should place data in additional information including:

- information on implementing and using standards defined in the Code of professional ethics in accounting

- information about obtained account books certificates

- the name of the entity that issued such certificates

- the period of time in which a certificate is valid

- information about developed and implemented standards whose aim is to ensure observance of ethical standards in accounting

- control procedure connected with observing ethical standards and creating ethical attitudes among workers

Only multi-directed information on account books certificate and observance of ethical standards will bring the desired effects and reach a wide group of users.

\section{Bibliography}

[1] Bergman, 1989. Ethique et gestion. [in:] Encyclopedie de gestion, Economica, Paris, pp. 1110-1120.

[2] D. Kopycińska, 1999. Wpływ aktualnej „wyceny” norm etycznych w Polsce na poglady przyszłych menedżerów. [in:] Etyka biznesu, J. Ditel, W. Gasparski, ed. PWN, Warszawa, p. 205.

[3] Niemczyk J., 2011. Metodologia nauk o zarzadzaniu. [in:] Podstawy metodologii badań w naukach 0 zarzadzaniu, W. Czakon, ed. Oficyna a Wolters Kluwer business, Warszawa, p. 26, see also A. Kaczmarczyk, 2003. Badania marketingowe. Metody i techniki. PWE Warszawa, p. 97.

[4] Sugahara S., Boland G., 2011. Faculties' perceptions of ethics in the accounting curriculum: a Japanese study. [in:] C. Jeffrey, Research on professional responsibility and ethics in accounting, Emerald Group Publishing Limited, Bingley, U.K., p. 198.

[5] Voss G., 2016.. Kształtowanie norm etycznych a odpowiedzialność zawodowa księgowych, Wydawnictwo Uczelniane Uniwersytetu Technologiczno-Przyrodniczego w Bydgoszczy pp. 163-182

[6] .Zuraw P., 2012. The Idea of Professional Ethics Code in Accounting Recommended by Accounting Association in Poland Annales. Ethics in Economic Life, 15, p. 125. 